\title{
Debates
}

\section{Class Power and Union Capacities: A Research Note on the Power Resources Approach ${ }^{1}$}

\author{
Alexander Gallas, University of Kassel, Germany
}

Arguably, the power resources approach (PRA) is the most elaborate and most significant attempt to establish a methodology for labour studies in recent years. It provides a toolkit for identifying sources of workers' power in capitalist societies. In my view, it has two particular strengths. First of all, it enables labour scholars to conduct strategic research that can help labour activists and trade unionists in their day-to-day-struggles. Second, it is a low-threshold approach that is easy to grasp and use. A significant number of students in the German programme of the Global Labour University, most of whom are closely aligned with organised labour, employ it when they write coursework or MA dissertations. Consequently, Stefan Schmalz, Carmen Ludwig and Edward Webster are right to argue in the Introduction to the recent Special Issue of the Global Labour Journal (2018: 113) that the PRA crosses the divide between academia and labour activism. Nevertheless, the approach is marked by certain theoretical shortcomings, which need to be addressed - not least because they have important political implications.

In this short research note, I focus on just one theoretical issue (the implicit transformation of class power as a relation into compartmentalised capacities of workers and workers' organisations) and one contribution to the debate (the Introduction by Schmalz et al.). A more detailed, critical assessment of the PRA can be found in a separate article (Gallas, 2016).

Schmalz et al. (2018: 115) start from the following assumption: "The PRA is founded on the basic premise that the workforce can successfully defend its interests by collective mobilisation of power resources in the structurally asymmetric and antagonistic relation between capital and labour". 2 This quote shows that for Schmalz et al. the PRA is informed by a Marxian understanding of class as a structurally conditioned relation of power and conflict: class power is exercised by workers mobilising their resources together while facing capital as an antagonist. The existence of this antagonist suggests that the relationship of forces between both sides impacts how resources can be mobilised, and what kind of strategic choices are available for labour.

Crucially, Schmalz et al. implicitly transform this relational notion of power into a compartmentalising one through how they understand power resources. They speak of "levels of

\footnotetext{
${ }^{1}$ I would like thank my fellow editors at the GLJ for detailed comments on a draft version, which helped me to clarify my ideas. Furthermore, I have benefitted greatly from a conversation with Bastian Schulz on the power resources of workers in countries of the Global South. To be clear, I have written this article in personal capacity; it does not represent the views of the Editorial Board as a whole. Any flaws and omissions are my own.

2 Strikingly, Schmalz et al. describe the capacity of workers "to act strategically" only as a defensive capacity. Why should this be the case? Surely, the histories of labour movements across the globe show that workers have been able, time and again, not just to defend but also to advance their interests.
} 
labour power"3 - that is, a neatly defined number of capacities at the disposal of workers when they are trying to advance their interests. "Structural power" refers to their ability to disrupt "the valorisation of capital"; "associational power" means that they have the option of forming "workers' associations"; "institutional power" consists in using "legally fixed rights" to their advantage; and "societal power" reflects the fact that they can gain strength through interacting "with other social actors" (Schmalz et al., 2018: 119). In consequence, the exercise of power is no longer a reflection of an antagonistic relation whose poles are capital and labour, but the use of a range of quantifiable capacities that are possessed by the side of labour. Workers' power is now described as something that workers and their movements and organisations 'have' - and what matters, first and foremost, is whether they use this possession efficiently and effectively to reach their goals. In other words, the focus, in this type of analysis, is on how power is 'used', and not on what power is 'used for'. This is fundamentally different from a relational analysis. If the relational route is taken, any collective activity of workers must be assessed in terms of how it reflects, and impacts on, the underlying class relations of forces. This includes examining what kind of effects the goals of workers' movements and organisations have on the relations of forces if they are achieved.

This point can be illustrated by looking in more detail at associational power. For Schmalz et al. (2018: 118), unions and parties are seen as organisational pools of workers' power, supplying workers with a range of capacities that they would not possess if they were not organised. It follows that successful unions and parties are instances of workers making good use of their associational power.

Undoubtedly, unions and parties have greatly contributed to strengthening labour vis-à-vis capital in many situations. But the conceptualisation of the PRA has the problematic consequence that any strategy of unions and parties where stated aims are achieved can be declared a successful exercise of workers' power - no matter what the effects are of this strategy on workers as a class. Sectionalism and collusion with management or with pro-business governments on the side of unions as well as accommodating strategies on the side of labour parties have delivered, in certain cases, some benefits for the rank-and-file of the organisations in question. However, they usually have extremely divisive effects on workers in society as a whole, thus weakening the overall position of labour. Furthermore, unions - in particular in countries in the Global South with huge informal sectors - often struggle to reach beyond very narrow constituencies. In these settings, union strategies may be geared to a small minority of workers and obstruct working-class formation in the sense of a process in which the collective agency of workers as a class and an antagonist of capital is strengthened. Finally, there is the persistent issue of union and party-political corruption, which contributes greatly to turning workers away from

\footnotetext{
${ }^{3}$ It is surprising that Schmalz et al. have chosen this term to refer to the capacity of workers to act collectively - and have done so without commenting on this terminological choice at all. In the Marxian tradition, 'labour power' has been figuring, for more than a century, as the translation of the German word Arbeitskraft, which refers to the transhistorical capacity of individual human beings to carry out work. This needs to be distinguished from the capacity of workers operating under the conditions of the capitalist mode of production to act collectively on the grounds of common needs and interests. Obviously, Schmalz et al. are free to use concepts in ways they see fit. But they explicitly build on the Marxian tradition, as their reference to "the antagonistic relation between capital and labour" demonstrates (see also Schmalz et al., 2018: 118). Consequently, their usage of 'labour power' is prone to give rise to confusion. Hence, I contend that speaking of 'workers' power' is much more appropriate, and I use this term in what follows when I refer to what Schmalz et al. call 'labour power'.
} 
organised labour. In a nutshell, unions and labour parties can play an important part, under certain circumstances, in dividing workers and weakening them as a class.

In 2008, to provide just one example, the leaderships of the German transport union GDBA and the railway union Transnet cooperated closely with the management of Deutsche Bahn, the national railway service. Together, they set out a plan for a partial privatisation of the German railways (which was shelved in the end when the financial crisis hit the country). At the time, the unions claimed that their approach was successful insofar as Deutsche Bahn agreed as part of the deal that there would be no job losses due to privatisation until 2023. From a power resource perspective, one could see the agreement as resulting from an effective use of associational power: the unions used their weight to win a job guarantee and avert the worst. But arguably, this contributed to producing deep divisions among railway workers, many of whom were opposed to privatisation. The opposition against the deal grew even stronger once it became known shortly after it had been struck that the leader of Transnet during the negotiations, Norbert Hansen, would become the chief human resources officer at the company and a member of its executive board. Indeed, Hansen's decision to join the ranks of top-level management was seen as an act of betrayal by many workers opposed to the plan. It strengthened a competitor of the two unions, the Union of German Traindrivers (GDL), which was known for its confrontational stance towards management and its willingness to engage in industrial action. The example shows that it is not just necessary to discuss whether the GDBA and Transnet won concessions thanks to their associational power, but to examine the deal they made in a broader context. This includes asking what the unions used their organisational capacities for, and what the effects were for workers in the sector and for labour more generally.

In my view, this can be done by assessing the strategic options and choices of organised labour with reference to the relationship of forces between labour and capital. In other words, it needs to be asked what a truly relational conception of class power and union and party capacities would look like. It is beyond the scope of this short research note to provide a comprehensive theorisation. What I can offer instead is a brief sketch of a materialist conception of trade unions, which could serve as a starting point for such an undertaking. This can be found in the work of Josef Esser, one of the eminent figures in post-war West German materialist state theory and labour studies. According to Esser (1982: 244), trade unions are "intermediary organisations" operating between civil society and the state (emphasis in the original). They oscillate between acting, on the one hand, as "class organisations facilitating the pursuit of the economic interests of wage dependent people" (p. 228) and, on the other hand, as instances of "mass integration" mediating between the interests of capital and labour in a form that is conducive to the reproduction of capitalist class domination (p. 245). Following Esser (1982: 239-40), the functioning of unions is a reflection of both the class struggles taking place against the backdrop of the given class relations of forces, and the strategic selectivities that result from the fact that they operate on the terrain of the capitalist state.

Notably, the conditions under which unions operate are transformed all the time because the patterns of capital accumulation and class conflict constantly change. This also means that strategic selectivities inherent in the state may be contained or deflected. And yet, they never stop to exist as fundamental tendencies as long as there is no fundamental rupture with the capitalist mode of production. Their workings can be illustrated with reference to trade union law, which tends to favour the reproduction of capitalist class domination. It creates a divide between

\footnotetext{
${ }^{4}$ The quotations from Esser's book are translations from the German produced by the author.
} 
legitimate and illegitimate forms of labour struggle and thus criminalises illegitimate forms. On the one hand, it provides workers with secure ways of voicing their discontent. On the other hand, labour unrest is decelerated and formalised, making it predictable and controllable. In numerous countries, political strikes are banned, and certain groups of workers, for example police or public sector workers more broadly, are not allowed to go on strike. There are situations when trade unionists defy such strike bans, in particular if they feel that there is mass support for their cause. But this does not render trade union law inoperable and comes with a risk. In other words, the strategic selectivities do not determine fully the strategic choices of trade unionists; this does not, however, mean that they cease to influence the strategic calculations behind those choices. All of this suggests that unions are not just organisations of struggle, but also fields of struggle between competing forces of labour with different strategies. Some of those strategies may be more in line with unions as class organisations and some with unions as organisations of mass integration, and they can change over the life course of a single union.

In conclusion, any investigation seeking to identify opportunities for the strengthening of workers' power has to start from a class analysis - an analysis that identifies the existing class relations of forces and the economic, political and cultural class struggles that are taking place at a given time and in a given space. ${ }^{5}$ If the 'basic premise' of the PRA that there is class antagonism and domination is taken seriously, it is of limited use to just ask how a specific union can use the resources at its disposal to achieve its aims. It also needs to be asked what the effects of achieving these aims are on class relations. In other words, the capacities of unions and parties as such cannot be seen simply as reflections of workers' power. Their analysis must rather assess whether strategies of forces representing workers in one way or another make use of them so that this contributes to working-class formation - or whether the result is working-class partition, a deepening of divides between workers.

\section{REFERENCES}

Bieler, A. (2018) Agency and the Power Resources Approach: Asserting the Importance of the Structuring Conditions of the Capitalist Social Relations of Production. Global Labour Journal, 9(2): 243-248.

Esser, J. (1982) Gewwerkschaften in der Krise. Frankfurt/M: Suhrkamp.

\footnotetext{
${ }^{5}$ Obviously, class struggles vary greatly over times and places - and so do the institutions on the grounds of which they take place. This implies that a class analysis of the suggested type is a conjunctural analysis (Gallas, 2016). It asks what the class effects are of mobilising the capacities of unions and parties for a specific strategy in a specific situation. Commenting on my commitment to conjunctural analysis, Andreas Bieler (2018: 245) argues in his contribution to the GLJ Special Issue on the PRA that I neglect "the more fundamental structuring conditions of the capitalist social relations of production, resulting from the way in which production is set up". This critique results from a misconception of how situations are examined in the tradition of Conjunctural Marxism. The point of conjunctural analysis is precisely that in order to understand what is situational about situations, it is necessary to understand what is not situational about them. Both the deep structures constituting the capitalist mode of production - with the capitalist relations of production at its heart - and the institutional configurations characterising the social formations in which this mode of production prevails are not specific to a situation (Gallas, 2017). However, taking them into account is indispensable for a conjunctural analysis of the type envisaged here. As I have argued in this short note, it is only possible to examine the effects of trade union strategies with a systematic understanding of the role of trade unions at the level of the capitalist mode of production which is exactly why I have introduced the work of Esser into the debate on the PRA.
} 
Gallas, A. (2016) There is Power in a Union: A Strategic-Relational Perspective on Power Resources. In Monetary Macroeconomics, Labour Markets and Development: Festschrift for Hansjörg Herr, edited by A. Truger, F. Hein, M. Heine and F. Hoffer. Marburg: Metropolis.

Gallas, A. (2017) Conjunctural Marxism: Althusser and Poulantzas on the Capitalist State. Rethinking Marxism, 29(2): 256-280.

Schmalz, S., C. Ludwig and E. Webster (2018) The Power Resources Approach: Developments and Challenges. Global Labour Journal, 9(2): 113-134.

\section{BIOGRAPHICAL NOTE}

Alexander Gallas is an assistant professor at the Department of Politics, University of Kassel. He serves on the Editorial Board of the Global Labour Journal and has authored a monograph called The Thatcherite Offensive: A Neo-Poulantrasian Analysis (Haymarket, 2017), which provides a detailed analysis of the restructuring of class relations through the interventions of the Thatcher and Major governments in 1980s and 1990s Britain. [Email: alexandergallas@,uni-kassel.de] 